\title{
"Reflection" Penciptaan Komposisi Dengan Menerapkan Rumus Matematis Refleksi
}

\author{
Adi Wijaya ${ }^{1}$
}

\begin{abstract}
The process of making works of art is a creative process that can be achieved in various ways, contemporary musical development today inevitably requires academics and practitioners to understand theories that support the process of making artwork, not only in terms of aesthetics and relationships to the environment but the in-depth responsibilities reviewed technical to the work itself. Technical mastery in the cultivation of good works can help and facilitate both the process and logical delivery to the general public and certainly can be understood so that messages brought the work to the public. Music is an objective phenomenon, one form of objectivity in the work of music is a correlation with mathematics that has the potential to be the source of creation.
\end{abstract}

Keywords: Creation of composition, mathematical reflection.

\begin{abstract}
Abstrak
Proses pembuatan karya seni merupakan proses kreatif yang dapat dicapai dengan berbagai cara, perkembagan musik kontemporer saat ini mau tidak mau mengharuskan akademisi maupun praktisi memahami teori yang menunjang proses pembuatan karya seni, tidak hanya dari segi estetis dan hubungan terhadap lingkungan tetapi pertanggungjawaban mendalam yang ditinjau secara teknis terhadap karya itu sendiri. Penguasaan teknis dalam penggarapan karya seni yang baik dapat membantu dan mempermudah baik secara proses maupun penyampaian yang logis ke masyarakat umum dan tentunya dapat dipahami agar pesan yang dibawa karya tersebut sampai ke masyarakat. Musik adalah fenomena objektif, salah satu bentuk objektivitas dalam karya musik adalah korelasi dengan matematika yang memiliki potensi untuk dijadikan sumber penciptaan.
\end{abstract}

Kata kunci: Penciptaan komposisi, matematis refleksi.

\footnotetext{
${ }^{1}$ Mahasiswa Penciptaan Musik, Program Paccasarjana Institut Seni Indonesia Yogyakarta, alamat korespondensi Perum Puspa Indah 1.C.9, RT 010/000. Bangunjiwo. Kasihan. Bantul
} 


\section{Pendahuluan}

Musik tidak dapat terlepas dari unsur matematis, keduanya saling berhubungan. Hal ini dapat dilihat melalui beragam fenomena musik yang dapat dijelaskan secara matematis. Sebagai contoh, keberadaan gelombang suara yang muncul hingga dapat ditangkap melalui telinga manusia, frekuensi suara yang memiliki nilai tertentu dapat membentuk nada yang dapat didengar. Musik pada dasarnya merupakan fenomena yang bersifat objektif, sedang pengetahuan tentang hubungan musik dengan matematika diawali dari Phytagoras. Sebagaimana diketahui, Phytagoras menemukan konsep harmoni yang kemudian dikembangkan menjadi akord dan tangga nada. Melalui hasil percobaan tersebut Phytagoras menghubungkan frekuensi getaran pada senar dengan jarak interval nada. Inilah awal penyempurnaan nada dalam sejarah musik.

Abad 17 merupakan awal dari bergesernya paradigma musik sebagai sains menjadi musik dalam perspektif seni, dan sains, berubah dari teori menjadi praktik. Catatan yang menghubungkan antara musik dengan matematika juga dapat ditemukan antara lain, berasal dari buku karangan Marin Mersenne berjudul Harmonie Universalie yang diterbitkan di Paris pada tahun 1636 berisikan tentang pengetahuan

musik yang luas mencakup teori, praktik, gaya, organologi, matematika dan teologi. Henrich Saviele (1619) pendiri kampus Oxford di bidang matematika menjelaskan secara terperinci bahwa musik merupakan kajian multidisiplin yang berkaitan erat dengan sains. Thomas Morley dalam bukunya Plaine and Easy Introduction to Music (1597), memuat tentang kajian musik secara ilmu pengetahuan dan analisis komposisi. Dalam buku ini disinggung notasi Phytagoras yang disebut sebagai "Harmony of The Spheres" tentang planet-planet yang membuat musik seiring pergerakan planet-planet tersebut. Masing-masing memiliki suara yang berbeda, tergantung dari jarak planet tersebut dengan bumi. Lebih lanjut Thomas Morley juga menunjukkan bagaimana proporsi 6:4:3 dapat membentuk interval $\mathrm{C}-\mathrm{G}$ dan $\mathrm{C}$ ' untuk satu oktaf yang lebih tinggi. 
Perkembangan lain mengenai hubungan musik dan matematika dilakukan oleh Iannis Xenakis, salah satu pionir dalam pengembangan musik elektronik, Xenakis mengintegrasikan musik dengan matematika, arsitektur dan desain. Xenakis menggunakan kalkulus diferensial untuk menciptakan musik, metodenya disebut musik formal. Dikatakan oleh Xenakis dalam bukunya Formalized Music Thought and Mathematics in Composition bahwa baik atau buruk tidak bermakna sama sekali untuk suara, maupun musik yang dihasilkan oleh suara tersebut. Jumlah pemahaman yang dihasilkan oleh suara harus menjadi kriteria validitas musik tertentu. Dalam buku tersebut, Xenakis menjabarkan bahwa metode komposisi yang digunakan dalam beberapa karya-karyanya juga dalam buku tersebut, layaknya sebuah buku teori matematika yang dipenuhi dengan persamaan-persamaan matematis.

Aspek matematis dapat berupa pembentukan harmoni dan tangga nada, Phytagoras telah memulai dengan membentuk susunan tangga nada melalui percobaan pada papan dan senar. Sistem tangga nada yang dibuat Phytagoras berdasarkan rasio 3:2 yang dapat disebut sebagai perfect fifth. Tangga nada ini disusun menggunakan interval kelima dan oktav sebagai acuan. Metode ini disebut sebagai Phytagoryan Tuning, sedangkan metode ini didapat dengan cara menyusun interval kelima, menggunakan rasio 3:2 dan 2:1 (oktaf). Contoh pada tuning nada D melalui Phytagoryan Tuning akan didapat susunan nada : D-A-E-B-F\#-C\#-G\# (bergerak naik) dan E $b$-B b F-C-G-D (bergerak turun). Jika D distem pada frekuensi $288 \mathrm{~Hz}$ maka agar sesuai dengan rasio 3:2 nada A distem pada frekuensi $432 \mathrm{~Hz}$, begitu pula seterusnya. Contoh lain dalam pembuatan materi tangga nada adalah metode Stochastic yang dibuat oleh Ianis Xenakis. Dalam metode ini Xenakis menggunakan 28 kolom dan 7 baris, setiap baris mewakili instrumen dan tiap kolom mewakili periode waktu. Xenakis menciptakan susunan waveform secara acak yang dikombinasikan dengan periode waktu menggunakan metode stokastik, yaitu mengolah satu waveform menggunakan algoritma sintetis. Contoh, jika diasumsikan 
bahwa suara $J$ adalah serangkaian gelombang polygonal, maka jumlah gelombang $j$ didefinisikan dengan indeks $I$. berikut adalah kordinat yang disusun.

$$
\left(x_{i, j}, y_{i, j}\right), 0 \leq i<I, 0 \leq j<J .
$$

Koordinat ${ }^{x_{i, j}}$ adalah sample nomor ${ }^{y_{i, j}}$ merupakan integer 16 - bit, dilanjutkan dengan dua waveform secara berurutan. Hasil yang didapatkan dengan memasukkan algoritma tersebut sesuai dengan grafik polygonal seperti berikut ini.

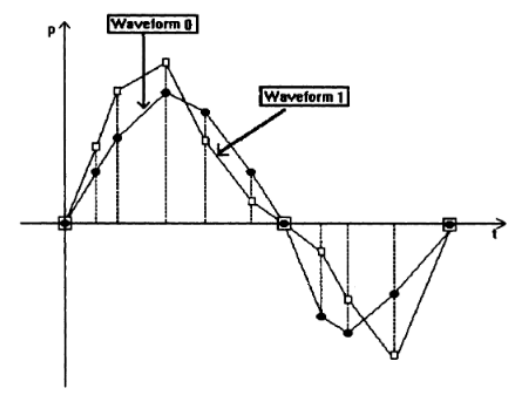

Berdasarkan pernyataan Xenakis bahwa kategori estetis dari musik bukan lagi kriteria subjektif, melainkan objektif. Sebagai seni matematis dan fisis, musik tidak lagi memenuhi perannya sebagai sesuatu yang misterius yang menunggu makna-makna tersembunyi. Musik adalah kepanjangan tangan dari ilmu pasti dan akhirnya menjadi ilmu pasti.

Terinspirasi dari tokoh tersebut, penulis melihat korelasi antara musik dengan matematika memiliki potensi untuk dijadikan sumber penciptaan, bahwa penciptaan karya musik dapat bersumber dari teori matematika. Adapun ide penciptaan penulis berasal dari rumus matematis refleksi. Pencerminan atau refleksi adalah suatu transformasi yang memindahkan setiap titik pada bidang dengan menggunakan sifat bayangan cermim. Refleksi mempunyai titik dan garis invarian, titik invarian yaitu titik yang berada pada cermin dan garis invarian pada refleksi adalah garis yang berimpit dengan cermin (Sartono, 2006:196). 


\section{Sifat dari refleksi:}

1. Jarak suatu titik terhadap cermin sama dengan jarak antara pencerminan dengan cermin

2. Garis yang menghubungkan titik dengan pencerminannya selalu tegak lurus dengan cermin.

3. Setiap garis dan pencerminannya selalu sama panjang

4. Setiap bangun dan pencerminannya selalu kongruen

Tantangan yang dihadapi adalah merumuskan tangga nada secara matematis sudah dilakukan lebih dari 1000 tahun yang lalu, sehingga untuk mencapai kebaruan perlu adanya studi kasus yang lebih mendalam. Tantangan lain adalah mencari perbedaan bunyi dari modus yang sudah ada, jadi bukan hal yang tidak mungkin temuannya hanya berupa material modus yang sudah ada. Sebagai contoh pada pembentukan modus menggunakan metode Thesaurus Melodic Pattern, dengan mengolah interval C\# - F\# - B dengan menggunakan interpolasi dua nada maka material tangga nada yang didapat berupa tangga nada $\mathrm{D}$ Mayor diatonic.

Interval C\# - F\# - B yang diinterpolasikan dengan 2 nada membentuk tangga nada diatonis D Mayor.

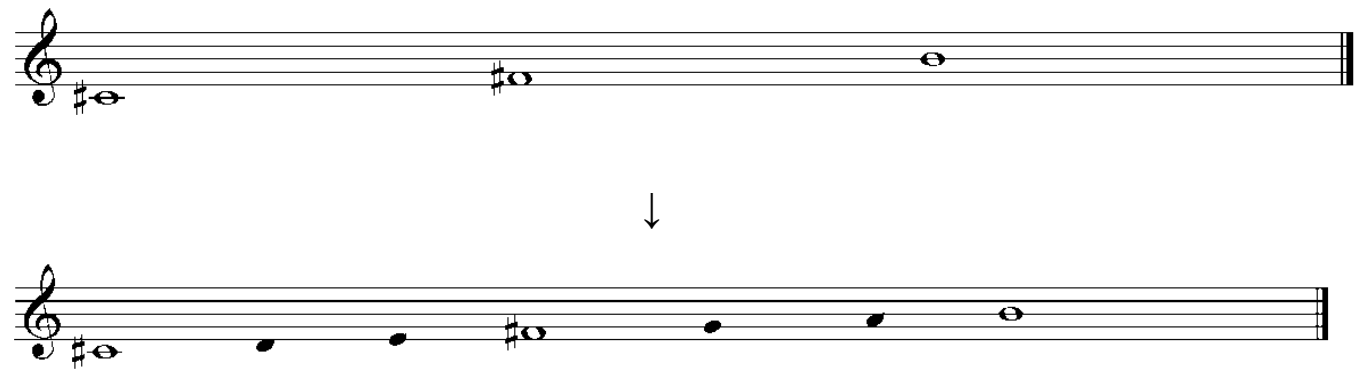

Tantangan lainnya merupakan hal yang bersifat subjektif, artinya hasil yang didapat belum tentu sesuai dengan aspek subjektif penulis, dengan kata lain hasilnya tidak dapat selaras dengan ekspresi kita. Oleh karena itu berdasarkan rumus refleksi ini, diharapkan mampu menghasilkan pilihan tangga nada yang beragam, sehingga 
permasalahan subjektivitas dapat teratasi dengan banyaknya pilihan yang sesuai dengan keinginan penulis. Melalui tantangan tersebut, terlihat penciptaan ini tidak lepas dari penelitian dan studi kasus yang lebih mendalam.

\section{Proses Penciptaan}

Berdasarkan pada pemaparan tersebut penentuan ide awal berasal dari kondisi lingkungan penulis, sehingga menjadi inspirasi untuk membuat karya musik. Penentuan ide awal ini berlangsung secara spontan dan dikuatkan melalui perbandingan referensi auditif dan pengumpulan data kajian untuk mencari relevansi dengan karya yang diinginkan. Proses pembuatan karya "Reflection" dilakukan dengan tahapan secara beruntun. Tahapan penetapan ide awal dilakukan dengan mengobservasi karya-karya yang sebanding dan relevan. Tahapan observasi ini dilakukan dengan mendengar, menganalisis melalui audio, partitur/score, sebagai landasan untuk mengaplikasikan karya ke dalam proses penggarapan. Proses penggarapan komposisi ini, penulis menggunakan sistem musik barat yang sudah biasa digunakan oleh para komponis dari era sebelumnya. Proses penggarapan karya "Reflection" menggunakan bentuk pengembangan dari konsep musik tonal dan polytonal. Dengan penggarapan yang bersifat subjektif dari penggabungan unsurunsur musikal yang digunakan.

Tahapan perancangan dalam penciptaan karya musik secara umum menyusun rancangan unsur musikal yang digunakan. Pada tahapan ini setelah melakukan penentuan ide melalui beberapa karya terdahulu yang memiliki kesamaan tema maupun konsep, serta pengumpulan data, proses selanjutnya adalah tahap perancangan. Langkah awal yang dilakukan pada tahap ini adalah merancang unsur musikal yang meliputi struktur melodi dan akor. 


\section{Pembentukan Modus}

Pembentukan modus menggunakan persamaan rumus matematis refleksi, contoh di bawah ini adalah penerapan rumus matematis refleksi yang digunakan sebagai persamaan untuk mendapatkan modus sintetis dari modus C Lydian.

Modus C Lydian yang direfleksi menggunakan sumbu $x$.

(a', b') dengan a' = a dan b; =-b

$$
\mathrm{A}(\mathrm{a}, \mathrm{b}) \quad \mathrm{B}(\mathrm{a},-\mathrm{b})
$$

Dalam penggunaan rumus ini perlu diketahui dalam setiap pencerminan terdapat titik sumbu $(0,0)$, sumbu $(0,0)$ pada modus terdapat nada pertama pada modus tertentu yang ingin direfleksikan, misal pada modus C Lydian interval antara $\mathrm{C}$ dengan $\mathrm{C}$ adalah 0 . Oleh karena itu titik sumbu $(0,0)$ pada tangga nada $\mathrm{C}$ Lydian adalah pada nada C. Dalam pembentukan modus yang dicerminkan melalui rumus matematitis refleksi hasil yang didapat merupakan hasil cerminan yang memiliki integral negatif, seperti pada contoh B (a,-b). Untuk dapat diterapkan ke dalam modus maka integral negatif didapatkan melalui pengurangan pada interval tertentu. Contoh pada modus C Lydian yang memiliki interval 1,2,3,3 1/2, 4 1/2 ,5 1/2, nada yang direfleksikan akan memiliki interval -1-2-3-3 $1 \frac{1}{2}-4$ - $1 \frac{1}{2}-5 \frac{1}{1 / 2}$. Untuk mendapatkan hasil pencerminan nada $\mathrm{C}$ sebagai titik sumbu $(0,0)$ dikurangi jarak interval. Hasil yang diperoleh melalui pencerminan interval tersebut adalah $\mathrm{C}, \mathrm{Bb}, \mathrm{Ab}, \mathrm{Gb}, \mathrm{F}, \mathrm{Eb}$, Db. Setiap modus yang direfleksikan akan memiliki beberapa kemungkinan modus yang dihasilkan, tergantung dari jumlah nada yang digunakan.

- Nada poros D yang direfleksi terhadap sumbu X

$$
\begin{gathered}
\left(\begin{array}{l}
1 \\
0
\end{array}\right)\left(\begin{array}{c}
0 \\
-1
\end{array}\right) \rightarrow\left(\begin{array}{c}
D \\
-D
\end{array}\right)=D,-D(1,-1) \\
D, B b \rightarrow 2 C-2=A b
\end{gathered}
$$




\section{Keterangan:}

$\mathrm{D}$ - Bb memiliki interval 2, karena pada pencerminan hasil yang didapat selalu negatif maka untuk memperoleh kemungkinan nada yang berbeda dilakukan dengan menambahkan interval 2 yang bergerak turun dari titik sumbu $(0,0)$, yaitu pada nada $\mathrm{C}$ bergerak turun dengan interval 2 , nada yang diperoleh yaitu $\mathrm{Ab}$, lebih jelasnya adalah sebagai berikut.

$$
\begin{aligned}
& \left(\begin{array}{c}
D \\
-E
\end{array}\right)=D,-E(1,-2) \\
& D, A s \rightarrow 3 C-3=F i s \\
& \left(\begin{array}{c}
D \\
-F i s
\end{array}\right)=D,-F i s(1,-3) \\
& D, G b \rightarrow 4 C-4=E \\
& \left(\begin{array}{c}
D \\
-G
\end{array}\right)=D,-G\left(1,-3 \frac{1}{2}\right) \\
& D, F \rightarrow 4 \frac{1}{2} C-4 \frac{1}{2}=E b \\
& \left(\begin{array}{c}
D \\
-A
\end{array}\right)=D,-A\left(1,-4 \frac{1}{2}\right) \\
& D, E b \rightarrow 5 \frac{1}{2} C-5 \frac{1}{2}=C \# \\
& \left(\begin{array}{c}
D \\
-B
\end{array}\right)=D,-B\left(1,-5 \frac{1}{2}\right) \\
& D, D b \rightarrow 6 \frac{1}{2} C-6 \frac{1}{2}=B
\end{aligned}
$$

C Lydian dengan nada D sebagai poros direfleksikan menjadi $\mathrm{C}-\mathrm{C} \#-\mathrm{Eb}-\mathrm{E}-\mathrm{F} \#-\mathrm{Ab}-\mathrm{B}-\mathrm{C}$ 
- Nada poros E yang di refleksi dengan Sumbu X

$$
\left(\begin{array}{l}
1 \\
0
\end{array}\right)\left(\begin{array}{c}
0 \\
-1
\end{array}\right) \rightarrow\left(\begin{array}{l}
E \\
D
\end{array}\right)=E,-D(E, B b) \rightarrow 3, C-3=F \#
$$

\section{Keterangan:}

$\mathrm{E}$ - Bb memiliki interval 3, karena pada pencerminan hasil yang didapat selalu negatif maka untuk memperoleh kemungkinan nada yang berbeda dilakukan dengan menambahkan interval 3 yang bergerak turun dari titik sumbu $(0,0)$, yaitu pada nada $\mathrm{C}$ bergerak turun dengan interval 3 , nada yang diperoleh yaitu F\#

$$
\begin{aligned}
& \left(\begin{array}{l}
E \\
E
\end{array}\right)=E,-E(E, A b) \rightarrow 4, C-4=E \\
& \left(\begin{array}{c}
E \\
F i s
\end{array}\right)=E,-F \#(E, G b) \rightarrow 5, C-5=D \\
& \left(\begin{array}{l}
E \\
G
\end{array}\right)=E,-G(E, F) \rightarrow 5 \frac{1}{2}, C-5 \frac{1}{2}=C \# \\
& \left(\begin{array}{l}
E \\
A
\end{array}\right)=E,-A(E, E b) \rightarrow 6 \frac{1}{2}, C-6 \frac{1}{2}=B \\
& \left(\begin{array}{l}
E \\
B
\end{array}\right)=E,-B(E, D b) \rightarrow 7 \frac{1}{2}, C-7 \frac{1}{2}=A
\end{aligned}
$$

C Lydian dengan nada E sebagai poros direfleksikan menjadi $\mathrm{C}-\mathrm{C} \#-\mathrm{D}-\mathrm{E}-\mathrm{F} \#-\mathrm{A}-\mathrm{B}-\mathrm{C}$

- Nada poros F\# dalam Modus C Lydian direfleksikan terhadap Sumbu X

$$
\left(\begin{array}{l}
1 \\
0
\end{array}\right)\left(\begin{array}{c}
0 \\
-1
\end{array}\right) \rightarrow\left(\begin{array}{c}
F \# \\
D
\end{array}\right)=F \#,-D(F i s, B b) \rightarrow 4, C-4=E
$$

\section{Keterangan:}

$\mathrm{F} \#$ - Bb memiliki interval 4, karena pada pencerminan hasil yang didapat selalu negatif maka untuk memperoleh kemungkinan nada yang berbeda 
dilakukan dengan menambahkan interval 4 yang bergerak turun dari titik sumbu $(0,0)$, yaitu pada nada $\mathrm{C}$ bergerak turun dengan interval 4 , nada yang diperoleh yaitu $\mathrm{E}$

$$
\begin{aligned}
& \left(\begin{array}{c}
F \# \\
E
\end{array}\right)=F \#,-E(F \#, A b) \rightarrow 5, C-5=D \\
& \left(\begin{array}{c}
F \# \\
F i s
\end{array}\right)=F \#,-F \#(F \#, G b) \rightarrow 6, C-6=C \\
& \left(\begin{array}{c}
F \# \\
G
\end{array}\right)=F \#,-G(F \#, F) \rightarrow 6 \frac{1}{2}, C-6 \frac{1}{2}=B \\
& \left(\begin{array}{c}
F \# \\
A
\end{array}\right)=F \#,-A(F \#, E b) \rightarrow 7 \frac{1}{2}, C-7 \frac{1}{2}=A \\
& \left(\begin{array}{c}
F \# \\
B
\end{array}\right)=F \#,-B(F \#, D b) \rightarrow 8 \frac{1}{2}, C-8 \frac{1}{2}=G
\end{aligned}
$$

C Lydian dengan nada F\# sebagai poros direfleksikan menjadi $C-D-E-F \#-G-A-B-C$

- Nada poros $\mathrm{G}$ dalam modus C Lydian yang direfleksi terhadap sumbu X

$$
\left(\begin{array}{c}
1 \\
0
\end{array}\right)\left(\begin{array}{c}
0 \\
-1
\end{array}\right) \rightarrow\left(\begin{array}{l}
G \\
D
\end{array}\right)=G,-D(G, B b) \rightarrow 4 \frac{1}{2}, C-4 \frac{1}{2}=E b
$$

\section{Keterangan:}

$\mathrm{G}$ - Bb memiliki interval $4 \frac{1}{2}$, karena pada pencerminan hasil yang didapat selalu negatif maka untuk memperoleh kemungkinan nada yang berbeda dilakukan dengan menambahkan interval $4 \frac{1}{2}$ yang bergerak turun dari titik sumbu $(0,0)$, yaitu pada nada $\mathrm{C}$ bergerak turun dengan interval $4 \frac{1}{2}$, nada yang diperoleh yaitu $\mathrm{Eb}$ 


$$
\begin{aligned}
& \left(\begin{array}{l}
G \\
E
\end{array}\right)=G,-E(G, A s) \rightarrow 5 \frac{1}{2}, C-5 \frac{1}{2}=D b \\
& \left(\begin{array}{c}
G \\
F \#
\end{array}\right)=G-F \#(G, G b) \rightarrow 6 \frac{1}{2}, C-6 \frac{1}{2}=B \\
& \left(\begin{array}{l}
G \\
G
\end{array}\right)=G,-G(G, F) \rightarrow 7, C-7=B b \\
& \left(\begin{array}{l}
G \\
A
\end{array}\right)=G,-A(G, E b) \rightarrow 8, C-8=A b \\
& \left(\begin{array}{l}
E \\
B
\end{array}\right)=E,-B(E, D b) \rightarrow 9, C-9=G b
\end{aligned}
$$

C Lydian dengan nada $\mathrm{G}$ sebagai poros direfleksikan menjadi $\mathrm{C}-\mathrm{Db}-\mathrm{Eb}-\mathrm{Gb}-\mathrm{Ab}-\mathrm{Bb}-\mathrm{B}-\mathrm{C}$

- Nada poros A dalam modus C Lydian direfleksikan terhadap sumbu X

$$
\left(\begin{array}{l}
1 \\
0
\end{array}\right)\left(\begin{array}{c}
0 \\
-1
\end{array}\right) \rightarrow\left(\begin{array}{l}
A \\
D
\end{array}\right)=A,-D(A, B b) \rightarrow 5 \frac{1}{2}, C-5 \frac{1}{2}=C \#
$$

\section{Keterangan:}

$\mathrm{A}$ - Bb memiliki interval 5 1/2, karena pada pencerminan hasil yang didapat selalu negatif maka untuk memperoleh kemungkinan nada yang berbeda dilakukan dengan menambahkan interval 5 1/2 yang bergerak turun dari titik sumbu $(0,0)$, yaitu pada nada $\mathrm{C}$ bergerak turun dengan interval $5 \frac{1}{2}$, nada yang diperoleh yaitu $\mathrm{C \#}$

$$
\begin{aligned}
& \left(\begin{array}{l}
A \\
E
\end{array}\right)=A,-E(A, A s) \rightarrow 6 \frac{1}{2}, C-6 \frac{1}{2}=B \\
& \left(\begin{array}{c}
A \\
F \#
\end{array}\right)=A,-F \#(A, G b) \rightarrow 7 \frac{1}{2}, C-7 \frac{1}{2}=A
\end{aligned}
$$




$$
\begin{aligned}
& \left(\begin{array}{l}
A \\
G
\end{array}\right)=A,-G(A, F) \quad \rightarrow 8, C-8=G \# \\
& \left(\begin{array}{l}
A \\
A
\end{array}\right)=A,-A(A, E b) \quad \rightarrow 9, C-9=F \# \\
& \left(\begin{array}{l}
A \\
B
\end{array}\right)=A,-B(A, D b) \quad \rightarrow 10, C-10=E
\end{aligned}
$$

C Lydian dengan nada A sebagai poros direfleksikan menjadi $\mathrm{C}-\mathrm{C} \#-\mathrm{E}-\mathrm{F} \#-\mathrm{G} \#-\mathrm{A}-\mathrm{B}-\mathrm{C}$

- Nada poros B dalam modus C Lydian yang direfleksi dengan sumbu X

$$
\left(\begin{array}{l}
1 \\
0
\end{array}\right)\left(\begin{array}{c}
0 \\
-1
\end{array}\right) \rightarrow\left(\begin{array}{l}
B \\
D
\end{array}\right)=B,-D(B, B b) \rightarrow 6 \frac{1}{2}, C-6 \frac{1}{2}=B
$$

\section{Keterangan:}

$\mathrm{B}-\mathrm{Bb}$ memiliki interval $6 \frac{1}{2} 2$, karena pada pencerminan hasil yang didapat selalu negatif maka untuk memperoleh kemungkinan nada yang berbeda dilakukan dengan menambahkan interval $6 \frac{1}{2} 2$ yang bergerak turun dari titik sumbu $(0,0)$, yaitu pada nada $C$ bergerak turun dengan interval $61 / 2$, nada yang diperoleh yaitu B

$$
\begin{aligned}
& \left(\begin{array}{l}
B \\
E
\end{array}\right)=B,-E(B, A b) \rightarrow 7 \frac{1}{2}, C-7 \frac{1}{2}=A \\
& \left(\begin{array}{c}
B \\
F \#
\end{array}\right)=B,-F \#(A, G b) \rightarrow 8 \frac{1}{2}, C-8 \frac{1}{2}=G \\
& \left(\begin{array}{l}
B \\
G
\end{array}\right)=B,-G(B, F) \quad \rightarrow 9, C-9=F \# \\
& \left(\begin{array}{l}
B \\
A
\end{array}\right)=B,-A(B, E b) \quad \rightarrow 10, C-10=E
\end{aligned}
$$




$$
\left(\begin{array}{l}
B \\
B
\end{array}\right)=B,-B(A, D b) \quad \rightarrow 11, C-11=D
$$

C Lydian dengan nada B sebagai poros direfleksikan menjadi $\mathrm{C}-\mathrm{D}-\mathrm{E}-\mathrm{F} \#-\mathrm{G}-\mathrm{A}-\mathrm{B}-\mathrm{C}$

Kemungkinan yang dapat dicapai dalam membentuk modus sintetis berdasarkan refleksi dari modus C Lydian adalah sebagai berikut.

1. $\mathrm{C}-\mathrm{C} \#-\mathrm{Eb}-\mathrm{E}-\mathrm{F} \#-\mathrm{G} \#-\mathrm{B}-\mathrm{C}$

2. $\mathrm{C}-\mathrm{C} \#-\mathrm{D}-\mathrm{E}-\mathrm{F} \#-\mathrm{A}-\mathrm{B}-\mathrm{C}$

3. $\mathrm{C}-\mathrm{D}-\mathrm{E}-\mathrm{F} \#-\mathrm{G}-\mathrm{A}-\mathrm{B}-\mathrm{C}$

4. $\mathrm{C}-\mathrm{Db}-\mathrm{Eb}-\mathrm{Gb}-\mathrm{Ab}-\mathrm{Bb}-\mathrm{B}-\mathrm{C}$

5. $\mathrm{C}-\mathrm{C} \#-\mathrm{E}-\mathrm{F} \#-\mathrm{G} \#-\mathrm{A}-\mathrm{B}-\mathrm{C}$

\section{Pembentukan Sistem Harmoni}

a. Polytonal. Dalam harmoni polytonal stuktur harmoni dapat diperluas secara vertikal dengan menambahkan nada superimpose. Harmoni dengan sistem ini dibentuk dengan mengolah tangga nada yang telah direfleksikan ke dalam modus yang baru. Modus C Lydian yang dibentuk melalui proses refleksi menjadi tangga nada F \# Lydian dengan nada poros F\# adalah:

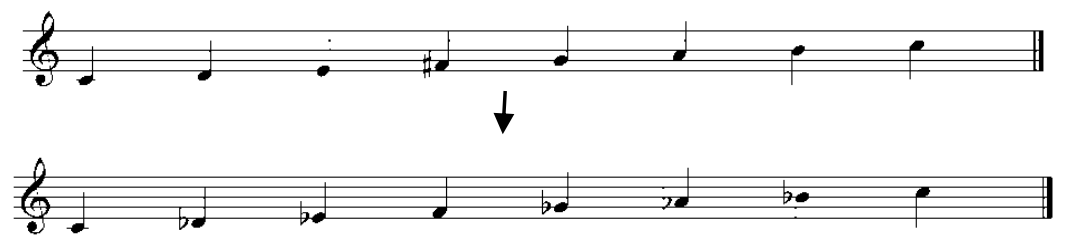

Harmoni yang digunakan pada tangga nada C Lydian adalah F\# Lydian dengan nada poros F\# 


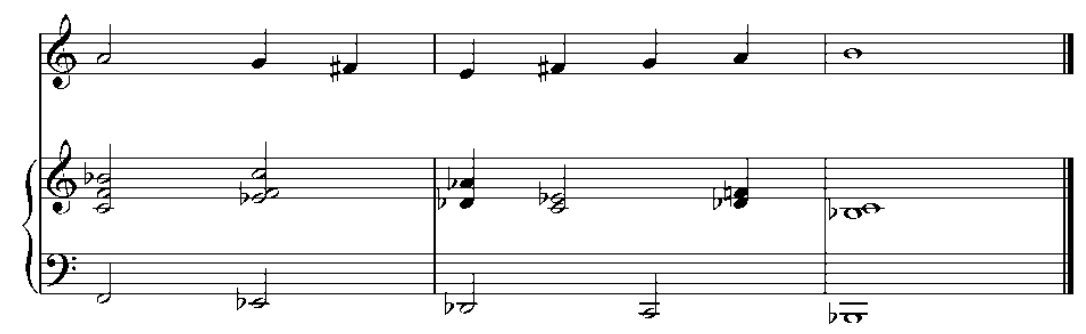

b. Penggunaan polychord dan compound harmony untuk dimensi suara disonan. Untuk mencapai tensi diperlukan adanya unsur ketegangan, dalam hal ini konsep tension and release sangat diterapkan dalam pembuatan karya ini. Untuk mengaplikasikan tension pada karya ini penulis menggunakan polychord yang dibentuk dari modus yang direfleksikan. Contoh penggunaan polychord pada modus yang direfleksikan, Modus C Lydian dengan menggunakan polychord berdasarkan refleksi dari tangga nada C Lydian yaitu F\# Lydian dengan nada F\# sebagai poros

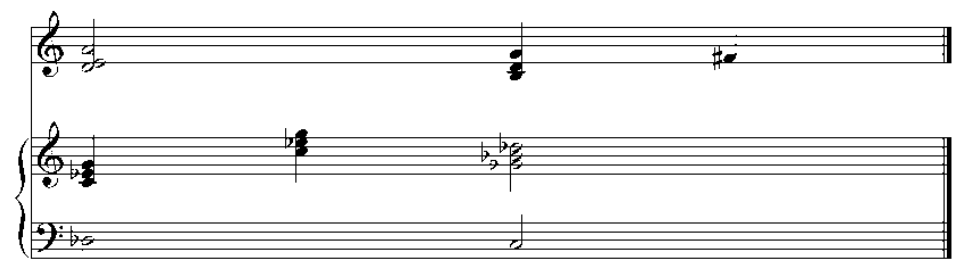

c. Harmoni kwartal. Unsur dari harmoni ini digunakan dengan merefleksikan interval dari modus yang dipilih, lalu disesuaikan dengan voicing dari harmoni kwartal.

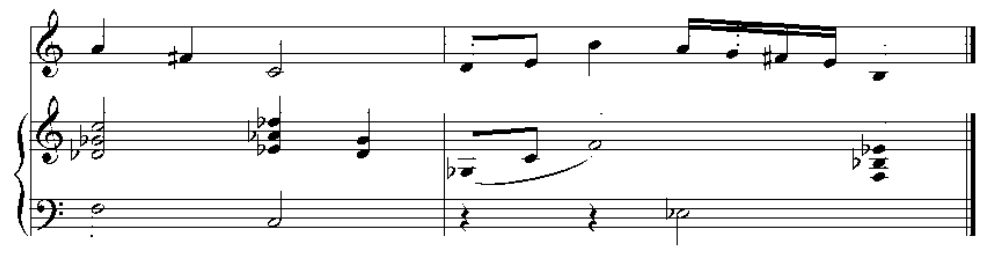




\section{Aplikasi Modus Dengan Konsep Progresi Akor}

Modus yang telah didapat melalui proses matematis refleksi digabungkan dengan konsep progresi akor, hal ini dapat terjadi apabila dalam keadaan tertentu membutuhkan suasana chordal. Contoh, tangga nada diatonis C Mayor sebagai melodi dengan iringan refleksi pada harmoni dalam tangga nada $\mathrm{Ab}$ mayor. Contoh di bawah menggunakan progresi ii - V7 - IM7

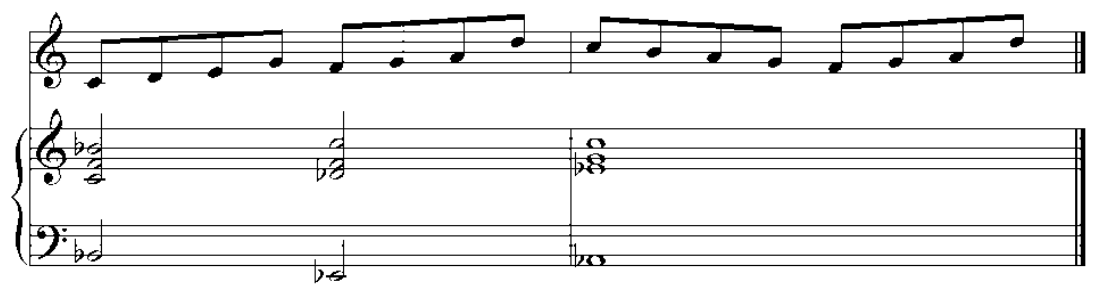

\section{Penyajian}

Hal yang harus dipertimbangkan setelah melakukan beberapa tahapan tersebut adalah tahapan penyajian. Dalam tahapan ini penulis menentukan beberapa langkah ataupun poin penting yang mencakup tentang penentuan pemain, waktu, dan tempat untuk proses latihan hingga pelaksanaan gladi kotor, gladi bersih, dan hari $\mathrm{H}$.

Pada penentuan pemain supaya tercapainya tujuan yang diharapkan, penulis harus mempertimbangkan kualitas kemampuan teknik pemain dari setiap instrumen yang ditentukan. Artinya penulis harus memilih setiap individu pemain yang mempunyai dan menguasai teknik ketrampilan instrumen dengan tingkat - skill yang tinggi. Dari kemampuan membaca full score, analisa unsur musikal, pertimbangan dinamika, tempo, dan etika dalam bermain musik ansambel (mencakup kesadaran untuk bekerja sama antar pemain). Hal ini bertujuan supaya tercapainya identitas esensi dari karya penulis pada saat hari pelaksanaan konser, yang mencakup sasaran akademis di dalam maupun di luar instansi, masyarakat, dan publik. 
Dalam penentuan waktu, yang harus penulis pertimbangkan adalah kesepakatan dan komunikasi dengan pemain, tim produksi dalam menentukan jadwal pertemuan, latihan, breafing, hingga evaluasi. Adanya beberapa pertimbangan tersebut tentunya bertujuan supaya terjadi kelancaran dalam proses latihan hingga pelaksanaan konser. Beberapa langkah dalam tahapan penyajian ini adalah rancangan yang harus dipertimbangkan, guna menunjukkan kualitas dari seorang seniman akademisi untuk mendapat pengakuan-tanggapan positif dari masyarakat.

\section{Kesimpulan}

Pembahasan tersebut dapatlah disimpulkan bahwa setiap karya komposisi musik tidak terlepas dari adanya suatu pengalaman tertentu. Pengalaman tersebut dapat menjadi sebuah stimulus untuk menentukan objek sebagai ide dasar dalam penggarapan karya musik. Hal tersebut dapat dikatakan sebagai kegelisahan dari para komponis, kreator seniman yang berperan sebagai sebab-musabab terciptanya sebuah karya seni. Setiap lingkungan dari para kreator tentunya dapat menentukan jenis-jenis karya seni berdasarkan pengalaman masing-masing, dengan gaya, bentuk, dan genre yang berbeda.

Dalam karya ini diorientasikan sebagai karya musik absolut dengan format instrumen chamber, ditampilkan sebagai bahasa musikal yang bersifat universal dengan pengembangan konsep musikal yang digunakan. Sebagaimana yang sudah

dipaparkan pada pembahasan tersebut, konsep karya ini merupakan sebuah pengembangan komposisi musik melalui refleksi dalam modus. Hal ini dapat dilihat dari landasan penciptaan hingga proses penciptaan.

Pada proses penggarapan komposisi musik terdapat kemungkinankemungkinan untuk menyusun, mengkombinasikan berbagai macam tone, interval, ritme, akord, dengan pengembangan yang lebih sistematis, subjektif, dan leluasa. Hal inilah yang mewujudkan tingkat kreativitas dalam berkarya sehingga keleluasaan 
musikal terus meningkat dan memperkaya khasanah musik di setiap lingkungan, masyarakat, dan kebudayaan.

\section{Daftar Pustaka}

Christ, William \& Richard Delone. tanpa tahun, Introduction to Materials And Structure of Music, New Jersey. Prentice Hall INC.

Hardjana, Suka. 2002, Corat-coret Musik Kontemporer Dulu dan Kini, Jakarta. Ford Fundation dan Masyarakat Seni Pertunjukan Indonesia.

.2004, Esai \& Kritik Musik, Yogyakarta Galang Press.

Kostka, Stefan. 2006, Materials \& Techniques of Twentieth Century Music, New Jersey. Pearson Prentice Hall.

Lester, Joel. 1981, Harmony in Tonal Music Volume I: Diatonic Practices, New York. The City College of The City University of New York.

Machlis, Joseph. 1955, The Enjoyment of Music: An Introduction to Perceptive listening. New York W. W. Norton \& Company. INC.

Marchuse, Herbert. 1969, Reason and Revolution Hegel and The Rise of Social Theory atau Rasio \& Revolusi Menyuguhkan kembali Doktrin Hegel untuk Umum, terjemahan Imam Baehaqie. 2004, Yogyakarta. Pustaka Belajar.

McNeill, Rhoderick J. 1998, Sejarah musik 2, Jakarta. BPK Gunung Mulia.

Miller, Ron. 1996, Modal Jazz Composition \& Harmony, Tubbingen. Advance

Music.

Persichetti, Vincent. 1961, Twentieth Century Harmony, Creative Aspects and Practice, London. Prentine-Rusell Square.

Russel, George. 1953. Lydian Chromatic Concept of Tonal Organization, Massachucets. Concept Publishing

Russo, William, et. al. 2004, A New Approach Composing Music, London. The University of Chicago Press, Ltd. 
Sacher, Jack \& James Eversole. 1977, The Art of Sound: An Introduction to Music, 2nd Edition, New Jersey. Prentice-Hall, Inc., Englewood Cliffs.

Slonimsky, Nicolas. 1947. Thesaurus of Scales And Melodic Pattern, New York. Amsco Publication.

Stein, Leon. 1979, Structure and Analysis of Musical Form, New Jersey. SummyBicard Music.

Ulehla, Ludmila. 1966. Contemporary Harmony, New York. The Tree Press.

Xenakis, Iannis. 1971. Formalized Music Thought and Mathematics in Composition, Indiana. Indiana University Press. 